\title{
New marine algal records from the Arabian Gulf coastline of Kuwait
}

\author{
Redha H. Al-Hasan*, Fatemah M. Al-Kherainej \\ Dept. of Biological Sciences, Faculty of Science, Kuwait University. \\ *Corresponding author: redha.alhasan@ku.edu.kw
}

\begin{abstract}
During 2014-2016, a project was launched to update and examine the current status of five phyla of benthic marine algae and epiphytic diatoms and marine Tracheophyta thriving along the coastal area of Kuwait. As a result, 173 species of algae were collected and identified. Fourteen new records of algal species for Kuwait, including 2 species as new records from the Arabian Gulf, are here reported for the first time. These species are assigned to the Chlorophyta (4), Ochrophyta (1), Rhodophyta (5), and Cyanobacteria (4). One species of marine angiosperm from the Kuwait coastal line is also found first. Five algal species collected from Kuwait coastal line remain unidentified.
\end{abstract}

Keywords: Benthic; Kuwait; marine algae; seagrass; systematic.

\section{Introduction}

Earlier biogeographical studies of the Arabian Gulf showed floristic affinities with distant regions, e.g., Japan, Australia, and South Africa (Børgesen 1934). The benthic algal flora of the Arabian Gulf represents an impoverished subset of that of the Indian Ocean (John \& AlThani, 2014). These findings fit the hypothesis of Hommersand (1986), who demonstrated that ocean currents during the Miocene are determinants for the present distribution patterns of the marine macro flora. The Arabian Gulf is not only geographically connected to the Arabian Sea but also subjected to heavy maritime traffic from all over the world, significantly introducing alien species.

The first list of the marine algal flora of Kuwait was mainly based on the three months collection of F. H. Kellet from April to June 1951, and the sample collections were done from Al-Ahmadi Port south of Kuwait, published by Newton (1955). "A field guide to the seashores of Kuwait and the Arabian Gulf" was published by Jones (1986), who listed the common algal species but without mentioning the sampling locations. Al-Hasan \& Jones (1989) reported 105 marine algae, of which 89 species were new records from Kuwait. Other investigations on marine algae, including some with ecological results, were conducted by Basson et al., (1977), Basson (1979 a, b), McCain (1984), McCain et al., (1984), Sheppard et al. (1992), and AlYamani et al., (2014). However, most of the smaller epiphytes and lithophytes have been overlooked or disregarded, particularly the Cyanobacteria, the minor studied group in the region and beset with many taxonomic and nomenclatural difficulties. Therefore, monitoring and updating the algal flora for this region are critical to updating the records of algal biodiversity. In addition, it will help understand the impact of local and worldwide marine activities on the ecosystem in this region. This paper presents new algal records for Kuwait and the Gulf region and offers scope for updating nomenclature and classification. 


\section{Materials and methods}

During October 2014 - 2016, sampling was frequently carried out biweekly during the fall to spring seasons and monthly to bi-monthly during the summer season, depending on low tide and weather conditions. The survey work was mainly focused on the littoral zone at 10 sampling sites along the northern to the southern coastal areas of Kuwait and Failaka Island (figure 1). Samples were processed for herbarium collection, and fresh samples were preserved with $2-3 \%$ formalin/seawater before the inspection.

At this stage, morphological and anatomical criteria were used to identify the algae. An updated nomenclature and classification analysis were used based on the published records. Currently accepted names in the most recent systematic online databases published by AlgaeBase (Guiry \& Guity 2021), Index Nominum Algarum (https://ucjeps.berkeley.edu/INA.html), and the Macroalgal Herbarium Portal (http://macroalgae.org/portal/index.php) were consulted.

For the region, synonyms mentioned in the earlier literature are included, under which the taxa are recorded. During his visit to our department, algal taxonomist Professor Michael Wynne, University of Michigan, helped in the identification and nomenclature of our marine algal collections.

Marine seagrasses also have been included in this study. Photomicrographs of the processed slides of the algal samples were obtained on a Carl Zeiss Axioskop 40FL epifluorescence microscope (Carl Zeiss, Berlin, Germany) equipped with AxioCam HR3 camera and imaging systems. Dry herbarium samples were deposited in the Kuwait University National Herbarium (KTUH).

\section{Results and discussion}

During the three years of this study, 173 algal species were recorded and classified as follows: Chlorophyta, 36 species from 2 classes, 5 orders, and 12 families; Ochrophyta, 36 species from two classes, 5 orders, and 8 families; Rhodophyta 57 species from 4 classes, 13 orders, and 21 families. Divergent groups of smaller epiphytic algae were observed, and some are described here. These included twenty-one epiphytic diatoms from 2 classes, 11 orders, and 15 families; Cyanobacteria, 23 species from 5 orders, and 14 families. Scattered seagrass meadows Halodule uninervis found on the Doha coast were covered with epiphytes and silty material. While on the southern coast, more extensive seagrass meadows of $H$. uninervis and H. ovalis were found. A large number of $H$. stipulacea were found drifting on the Al-Nuwaiseeb coast in the southern parts of Kuwait. It thrives in the subtidal zone offshore of the Saudi west coast

The observed changes in the algal record since 1998 may be attributed to several factors such as the sampling methods, sampling frequency, number and nature of the sampling site, and possible transportation of alien species through the increased marine and shipping activities in this region, including possible changes due to global warming changes. 


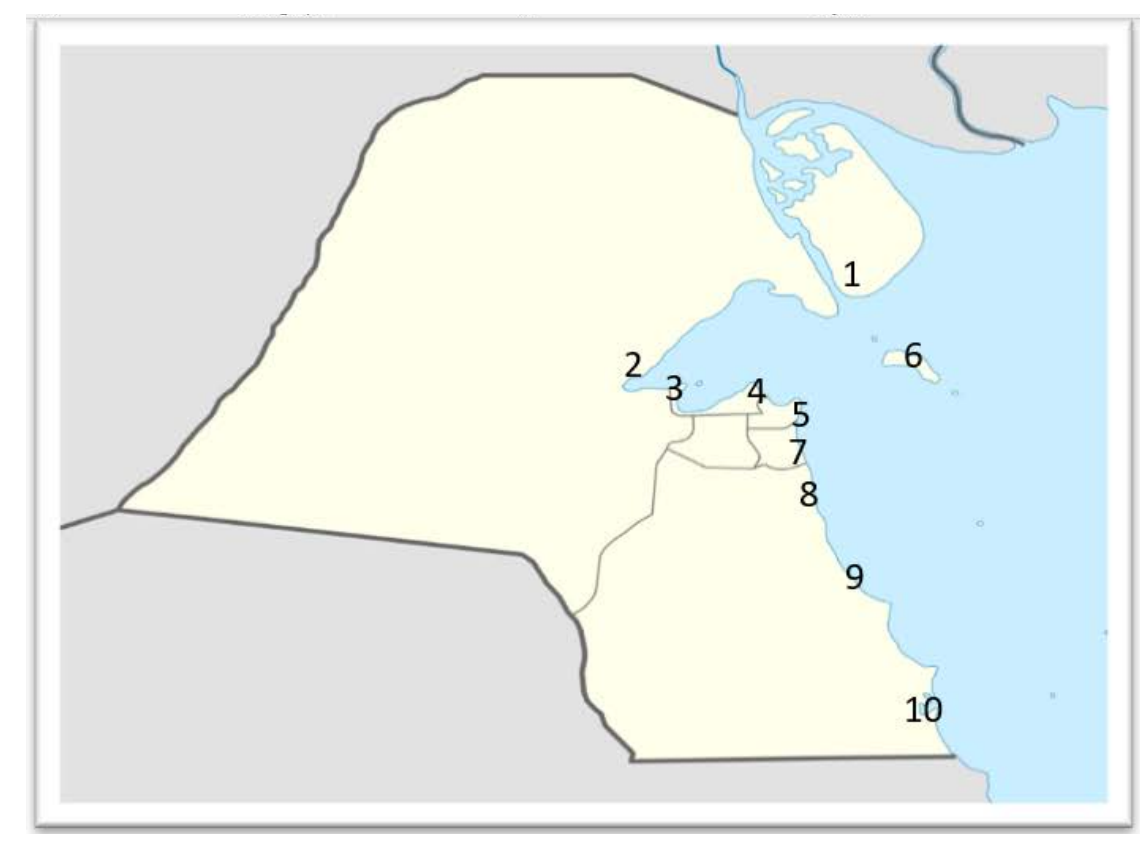

\begin{tabular}{|c|c|c|c|}
\hline $\begin{array}{l}\text { Site } \\
\text { No. }\end{array}$ & Sampling Location & Code & Coordinates \\
\hline 1 & Bubiyan Island & BUB & $\begin{array}{l}29^{\circ} 54^{\prime} 52.81^{\prime \prime} \mathrm{N} \\
48^{\circ} 8^{\prime} 17.08^{\prime \prime} \mathrm{E}\end{array}$ \\
\hline 2 & Al-Sabiyah & SAB & 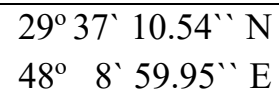 \\
\hline 3 & Do what Kathma & DKZ & $\begin{array}{ll}29^{\circ} 24^{\prime} & 0.57^{\prime \prime} \mathrm{N} \\
47^{\circ} 44^{\prime} & 36.60^{\prime \prime} \mathrm{E}\end{array}$ \\
\hline 4 & Al-Doha & $\mathrm{DOH}$ & $\begin{array}{cc}29^{\circ} 23^{\prime} & 2.32^{\prime \prime} \mathrm{N} \\
47^{\circ} 49^{\prime} & 32.26^{\prime \prime} \mathrm{E}\end{array}$ \\
\hline 5 & Kuwait Towers & KUT & 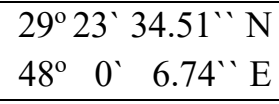 \\
\hline 6 & Failaka Island & FKI & $\begin{array}{lr}29^{\circ} 28^{\prime} & 9.44^{\prime \prime} \mathrm{N} \\
48^{\circ} 17^{\prime} & 15.02^{\prime \prime} \mathrm{E}\end{array}$ \\
\hline 7 & Al-Anjefa & ANJ & 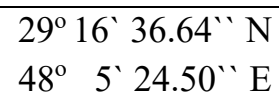 \\
\hline 8 & Abu Alhasannia & AHS & 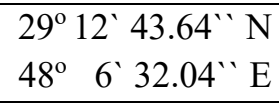 \\
\hline 9 & Al-Fintas & FNT & $\begin{array}{l}29^{\circ} 17^{\prime} 91.98^{\prime \prime} \mathrm{N} \\
48^{\circ} 12^{\prime} 26.48 " \mathrm{E}\end{array}$ \\
\hline 10 & Al-Nuwaiseeb & NOW & $\begin{array}{l}28^{\circ} 32^{\prime} 53.71^{\prime \prime} \mathrm{N} \\
48^{\circ} 25^{\prime} 45.73^{\prime \prime} \mathrm{E}\end{array}$ \\
\hline
\end{tabular}

Fig. 1. Map of Kuwait showing the sampling sites from north to south

The Al-Nuwaisseb coastal area in southern Kuwait is characterized by sandy banks stabilized by the seagrasses Halodule uninervis and less so by $H$. ovalis. Tidal pools are dominated by red algae growing clinging to the limestone rocks. The littoral zone is predominated by Palisada perforata, Palisada patentiramea, Acanthophora muscoides, Acanthophora nayadiformis, and Jania pumila. Green algae are represented by Dictyosphaeria cavernosa, Cladophoropsis fasciculata, and Caulerpa sertularioides. Brown algae occurring 
in the subtidal zone of southern Kuwait were identified as Sargassum angustifolium, Sargassum asperifolium, Sargassum aquifolium, Polycladia myrica, Sirophysalis trinodis, Hormophysa cuneiformis (Table 1). After stormy weather, the brown algae usually ends up on the beach in large masses cast upon the shore. Epiphytic microalgae are found on most of the collected algae and seagrass samples.

Kuwait Bay, a semi-enclosed bay in the North, showed less diversity and abundance of algae. The green algae mainly dominated this area, including Ulva lactuca, Ulva intestinalis, Ulva prolifera, Ulva clathrata, Chaetomorpha aerea, and Chaetomorpha linum. Brown algae such as Feldmannia mitchellae and a variety of Cyanobacteria were also found in this area (Table 1).

Heavy growth of green algae may be attributed to urban and residential expansions, anthropogenic and domestic/ industrial pollution, and high level of eutrophication, desalination plants, marinas, ports, and shipping traffic. Ballast water can also be a potential source of green algae and alien species. Bubiyan Island, Subiya, and most of the coast of northern Kuwait Bay are soft silty sediments that do not support macroalgal communities. Cyanobacteria and diatoms are the significant occupants of such an environment.

Coastal regions between areas such as Al-Anjafa, Abul Hasannia, and Al-Fintas are exposed to the open sea. They have rich algal diversity and an abundance of Colpomenia sinusa, Iyengaria stellata, Sphacelaria nova-hollandae, Sphacelaria rigidula, Padina gymnospora, Padina australis. Vaucheria pilobloides, and Gelidium pusilum (Table 1).

Table 1. Diversity of newly recorded algae in different sampling localities.

\begin{tabular}{|c|c|c|c|}
\hline Algal Phylum & $\begin{array}{c}\text { Northern sites } \\
\text { (Al-Doha, Kadhma, } \\
\text { Shuwaikh, Kuwait Towers) }\end{array}$ & $\begin{array}{c}\text { Middle sites } \\
\text { (Al-Anjefa, Al-Fintas, } \\
\text { Abul-Hassania) } \\
\end{array}$ & $\begin{array}{l}\text { Southern sites } \\
\text { (Al-Nuwaiseeb) }\end{array}$ \\
\hline Chlorophyta & Chaetomorpha ligustica & & $\begin{array}{l}\text { Entocladia polysiphoniae } \\
\text { Chaetomorpha vieillardii } \\
\text { Cladophoropsis fasciculata } \\
\end{array}$ \\
\hline Ochrophyta & Padina distromatica & Padina distromatica & \\
\hline Rhodophyta & $\begin{array}{l}\text { Hypnea cervicornis } \\
\text { Gracilaria } \mathrm{sp} .\end{array}$ & Polysiphonia scopulorum & $\begin{array}{l}\text { Stylonema alsidii } \\
\text { Chondria capillaris } \\
\text { Palisada patentiramea } \\
\end{array}$ \\
\hline Cyanobacteria & $\begin{array}{l}\text { Chamaesiphon incrustans } \\
\text { Rivularia bullata } \\
\text { Tolypothrix penicillata }\end{array}$ & & $\begin{array}{l}\text { Cyanothece halobia } \\
\text { Rivularia bullata } \\
\text { Scytonema sp (Failaka Island) } \\
\text { Tolypothrix penicillata }\end{array}$ \\
\hline Bacillariophyta & $\begin{array}{l}\text { Parlibellus sp. } \\
\text { Schizonema sp. } \\
\text { Geitlerinema sp. }\end{array}$ & & \\
\hline
\end{tabular}

Compared with the earlier records (Al-Hasan \& Jones, 1989), most algal species were present, except Scytosiphon lomentaria and Phaeocystis pouchetii that was absent throughout 
the survey at all visited stations. Grateloupia filicina, an alien species reported by AlYamani et al., (2014), was found thriving at the edge of the marina pier, indicating its possible introduction by shipping transport activities.

From the 173 identified algal species, 14 species were found to be new records for the Kuwait coastline and 2 species for the Arabian Gulf. These species were assigned to the Chlorophyta (4), Ochrophyta (1), Rhodophyta (5), and Cyanobacteria (4). One species of marine angiosperm is also reported for the first time in Kuwait. Al-Yamani et al., (2014) have reported additional 5 new species for the algal flora of the Kuwait coast since the publication by Al-Hasan \& Jones (1989).

A significant environmental catastrophe impacted the marine ecosystem for the coastline of Kuwait during the Gulf war in 1991 when more than 6 million US barrels of crude oil were spilled into the marine environment. At the same time, there was massive drainage of Mesopotamia marshes (Richardson \& Hussain, 2006). In addition, the vast expansion in urban development, population expansion, and active maritime shipping has adversely affected the marine ecosystems.

In addition, the sedimented nature of the coastal area has contributed to the abundance and diversity of algal species. It has been observed that the northern coastal areas characterized by considerable suspended matter and marshy nature and urban development have less algal diversity and abundance than the central and southern coastal regions. On the other hand, the coastal areas in the south region supported a better variety and abundance of algal species. This difference may be due to the sandy and rigid substrate intertidal zone being exposed to open sea and wave impact and the lesser urban developments and anthropogenic activities.

3.1 Systematic account

$*=$ New record for the Kuwait coast.

**=New record for the Arabian Gulf.

\subsubsection{Chlorophyta}

Ulvophyceae

Ulvales

Ulvellaceae

Entocladia Reinke, 1879

Entocladia polysiphoniae** Setchell \& Gardner 1924: 718. (figure 2A)

Thallus minute consists of prostrate, branched filaments of the square to rectangular cells in the surface view and resting parallel to the host surface.

Location: Al-Nuwaiseeb, Epiphytic on the surface of Chondria. May 2014. 
Cladophorales

Cladophoraceae

Chaetomorpha Kützing, 1845

Chaetomorpha ligustica** (Kützing) Kützing 1849. (figures 2B-D)

Synonym: Chaetomorpha capillaris (Kützing) Børgesen, nom. illeg. 1925.

Thallus forms soft and entangled light to dark green clumps of fine filaments. Filaments are uniseriate unbranched erect and attached with an enlarged, thick-walled basal cell, or they may be unattached without basal cells.

Location: Shuwaikh port free zone, tangled with other seaweeds. December 2015.

Chaetomorpha vieillardii* (Kützing) M.J. Wynne 2011.

Wynne (2011), John \& Al-Thani (2014).

This species is similar to $C$. ligustica but slightly harder to the touch and is composed of much larger cells. Its name Chaetomorpha vieillardii was proposed to apply for a tropical collection of Chaetomorpha with a larger cell size that had been formerly identified as $C$. crassa, a species regarded to be conspecific with C. linum. (Wynne, 2011).

Location: Al-Nuwaiseeb, entangled with other seaweeds. April 2014, March 2015.

Cladophorales

Boodleaceae

Cladophoropsis Børgesen, 1905

Cladophoropsis fasciculata (Kjellman) Wille 1910*. (figures 2E-F).

Heterotypic synonym: Cladophoropsis sundanensis Reinbold

De Clerck \& Coppejans 1996, John 2005, Leliaert \& Coppejans 2006, John \& Al-Thani 2014, Kokabi \& Yousefzadi 2015.

The plant consists of dark green filaments with unilateral branching forming dense mats or tufts of interwoven filaments. Cells are coenocytic, cylindrical with variable length; lateral branches are shortest and have no transverse wall at their basis. The terminal part of branches and branchlets are rounded.

Location: Al-Nuwaiseeb, attached to rocks in subtidal zones. April-May 2014, September November 2015. 

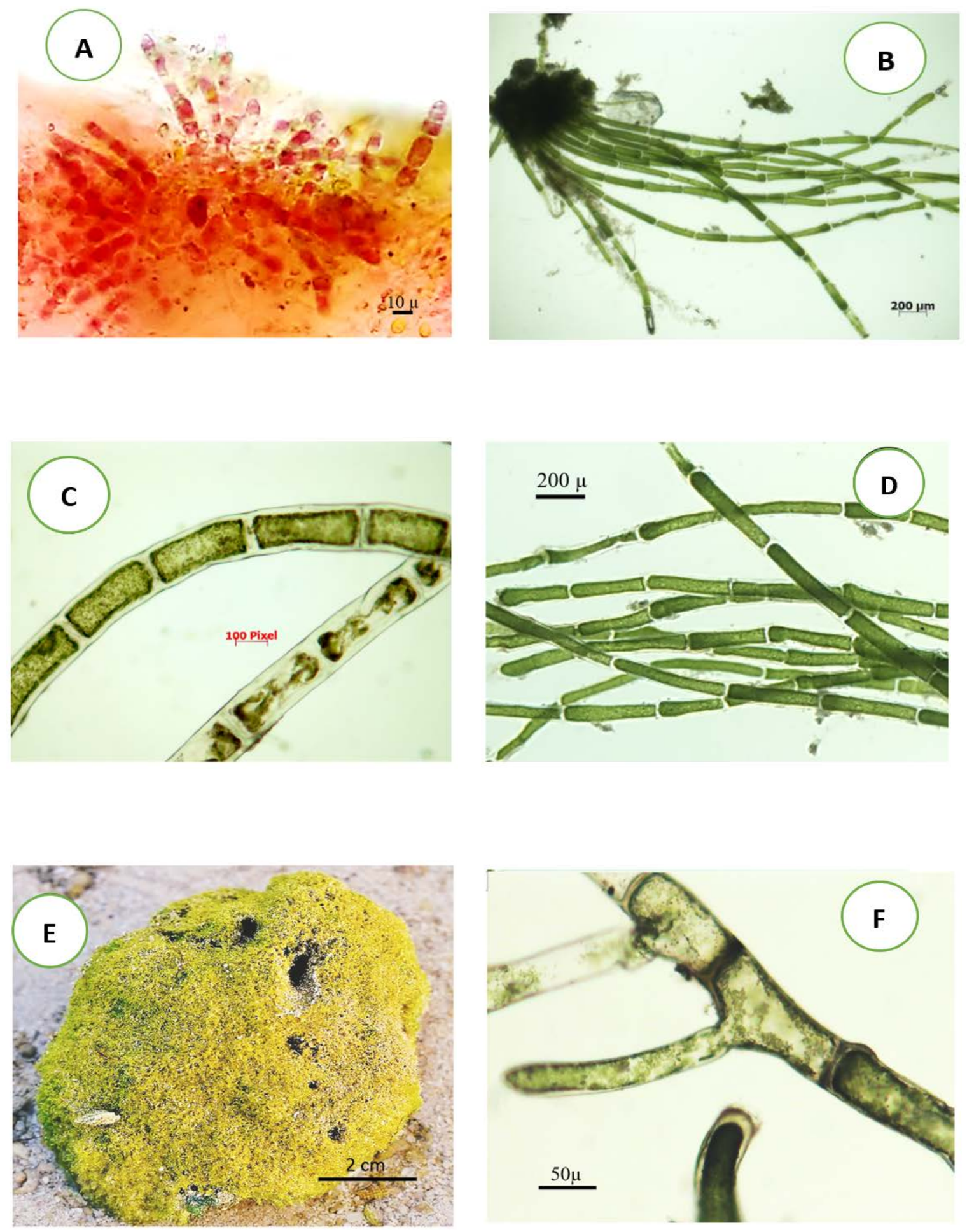

Fig. 2. Entocladia polysiphoniae (A) prostrate, branched filaments of square to rectangular cells in the surface view. Chaetomorpha ligustica (B-D)., filaments are uniseriate unbranched with multinucleated cylindrical cells. Cladophoropsis fasciculata (E-F), dark green filaments form tufts attached to stones. Filaments with dichotomous or trichotomous branching form dense mats. The thallus is composed of unilaterally to irregularly organized terminal branch systems, and the terminal portions of branches and branchlets are round. 


\subsubsection{Ochrophyta}

Phaeophyceae

Dictyotales

Dictyotaceae

Padina Adanson, 1763

Padina distromatica* Hauck 1887. (figure 3).

Allender \& Kraft, 1983; Abdel-Kareem, 2009.

The plants are reddish to light brown, membranous, with two layers of cells. And attain 3$5 \mathrm{~cm}$ in height. Sporangial rows alternate with hair rows at equal intervals and are not covered by an indusium.

Location: Al-Doha, Abul Hasannia, plants growing on rocks from mid intertidal to subtidal zones. November 2015.

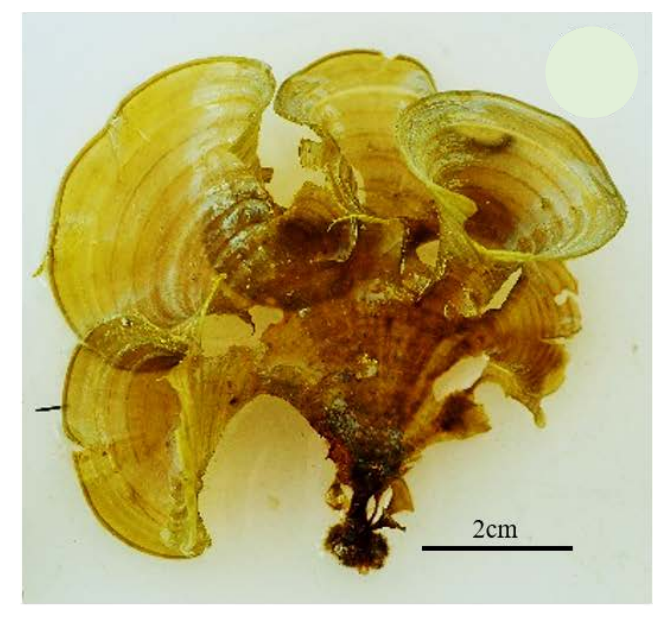

Fig. 3. Padina distromatica. Thalli are reddish to light brown, $3-5 \mathrm{~cm}$ in height. Sporangia rows alternate with hair rows at equal intervals not covered by an indusium.

\subsubsection{Rhodophyta}

Stylonematophyceae

Stylonematales

Stylonemataceae

Stylonema Reinsch 1875

Stylonema alsidii* (Zanardini) Drew 1956. (figure 4A).

Synonym: Goniotrichum alsidii (Zanardini) Howe 1914.

Sohrabipour \& Rabiei 1999, Wynne 1999, John \& Al-Thani 2014.

Thallus epiphytic, red to purple, and frequently branched. Filaments consist of a uniseriate row of closely adjacent cells within a thick mucilaginous sheath; cells are isodiametric with rounded to angular corners.

Location: Al-Nuwaiseeb; found epiphytic on Digenia and other algae; March 2015. 
Florideophyceae

Gigartinales

Cystocloniaceae

Hypnea J.V. Lamouroux, 1813

Hypnea cervicornis* J.Agardh 1851. (figure 4B).

Silva et al., 1996 (Iran: Sohrabipour \& Rabii 1999; Oman: Wynne 2018).

Thallus erects yellowish to red, up to $30 \mathrm{~cm}$ long, entangled bushy clumps. Uniaxial axes extend through the plant's entire length, dichotomous branching throughout, usually with many short lateral spine-like branchlets, branches terete to compressed. Axes terminated by a single protruding apical cell; medulla large-celled.

Location: Kuwait Towers, on rocks in subtidal pools. March 2015.

Ceramiales

Rhodomelaceae

Chondria C. Agardh, 1817

Chondria capillaris* (Hudson) M.J.Wynne, 1991. (figure 4C).

Heterotypic synonym: Chondria tenuissima (Withering) Agardh, 1817.

Silva et al.,1996, Abdel-Kareem 2009; John \& Al-Thani 2014.

The thallus is usually erect, much-branched irregularly radially or unilaterally. Branches terete or slightly compressed, young branches basally constricted. Apices of branches are depressed or rounded or tapering, with an apical filament usually 10-15 cells long. Rhizoids are typically sparse.

Location: Al-Nuwaiseeb, epilithic or epiphytic on Palisada patentiramea in the midlittoral zone. April 2014.

Palisada Nam, 2007

Palisada patentiramea* (Montagne) Cassano et al. 2009. (figure 4D).

Synonym: Laurencia patentiramea (Montagne) Kützing, 1849.

John \& Al-Thani 2014.

The plant is purple to dark red in color and cartilaginous. The branches are compressed in the middle to upper portions. Branchlets present distichously along the main branches, with a discoidal holdfast.

Location: Al-Nuwaiseeb, on stones in tidal pools; April-May 2014, November-December 2015. 
Polysiphonia Greville, 1823

Polysiphonia scopulorum* Harvey, 1855

Basson et al., 1989, Basson 1992, De Clerck \& Coppejans 1996, John \& Al-Thani 2014.

The thallus is dark red-brown, usually developing into spreading mats on rocks. Generally with an extensive and relatively prominent prostrate basal system with erect branches bearing a few lateral branches of similar diameter and arising independently of trichoblasts. Attachment by rhizoids from prostrate filaments.

Location: Abul Hasannia, epilithic, occasionally epiphytic. March 2014.
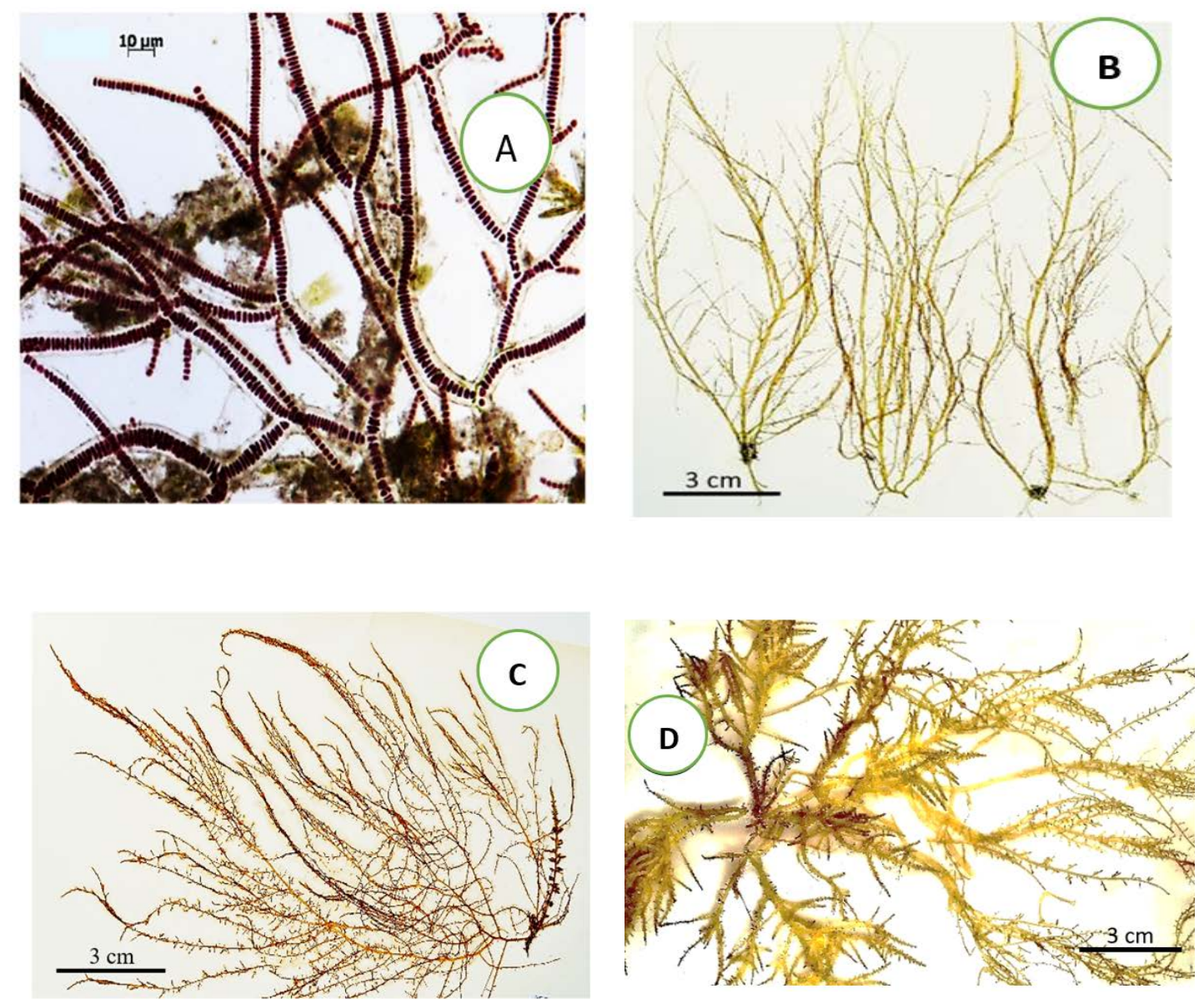

Fig. 4. Stylonema alsidii (Goniotrichum dichotomum) (A), filaments with a uniseriate row of closely adjacent cells within the thick mucilaginous sheath; cells isodiametric with rounded to angular corners. Hypnea cervicornis (B), thallus erect, yellowish to red, up to $30 \mathrm{~cm}$ long, entangled bushy clumps. Branches are short and pointed, with branchlets that appear tendril-like. Chondria capillaris (C), thallus erect, much-branched irregularly radially or unilaterally. Palisada patentiramea (D), the plant is purple to dark red in color and cartilaginous. Dense branchlets along the main branches. 


\subsubsection{Cyanobacteria}

Cyanophyceae

Synechococcales

Chamaesiphonaceae

Chamaesiphon A.Braun, 1864, nom. cons.

Chamaesiphon incrustans* Grunow (in Rabenhorst 1865).

The mature cell club-shaped, pear-shaped, ellipsoidal is differentiated into a basal end attached to a surface, and the distal end forms exospores.

Location: Kuwait Towers, found epiphytic on submerged algae. April 2016.

Oscillatoriales

Cyanothecaceae

Cyanothece Komárek, 1976

Cyanothece halobia* Roussomoustakaki \& Anagnostidis 1991. (figure 5A).

Unicellular with a thin mucilaginous outer layer, cells are large, usually bright blue-green to yellowish color contain many round granules or vesicles.

Location: Al-Nuwaiseeb, the biomass of epilithic unicellular oxygenic cyanobacteria in biofilms on the sandy littoral zone, April - May 2014.

Nostocales

Rivulariaceae

Rivularia C.Agardh ex Bornet \& Flahault, 1886.

Rivularia bullata * Berkeley ex Bornet \& Flahault, 1886. (figure 5B).

Berkeley, 1832.

Colonies are dark red containing many filaments; each includes a tapered trichome, which has a basal heterocyst and often ends in a long multicellular hair, No akinetes.

Location: Al-Nuwaiseeb, May 2014, and Al-Doha, epiphytic on red algae, February, May 2014.

Tolypothricaceae

Tolypothrix Kützing ex Bornet \& Flahault, 1886.

Tolypothrix penicillata *Thuret ex Bornet \& Flahault, 1886. (figure 5C).

Filamentous with a thin, firm sheath, colorless or typically yellow- to deep brown. False branched, branches single, mostly subtended by a heterocyst. Apices are often broader, with shorter cells. The colony forms a penicillate cushion or tuft. The pattern of repeated branching, with branches running quite close to the original filaments, often leads to a filamentous structure.

Location: Failaka Island, Do what Kazma, on rocks and in tidal pools. March 2014, October 2015. 

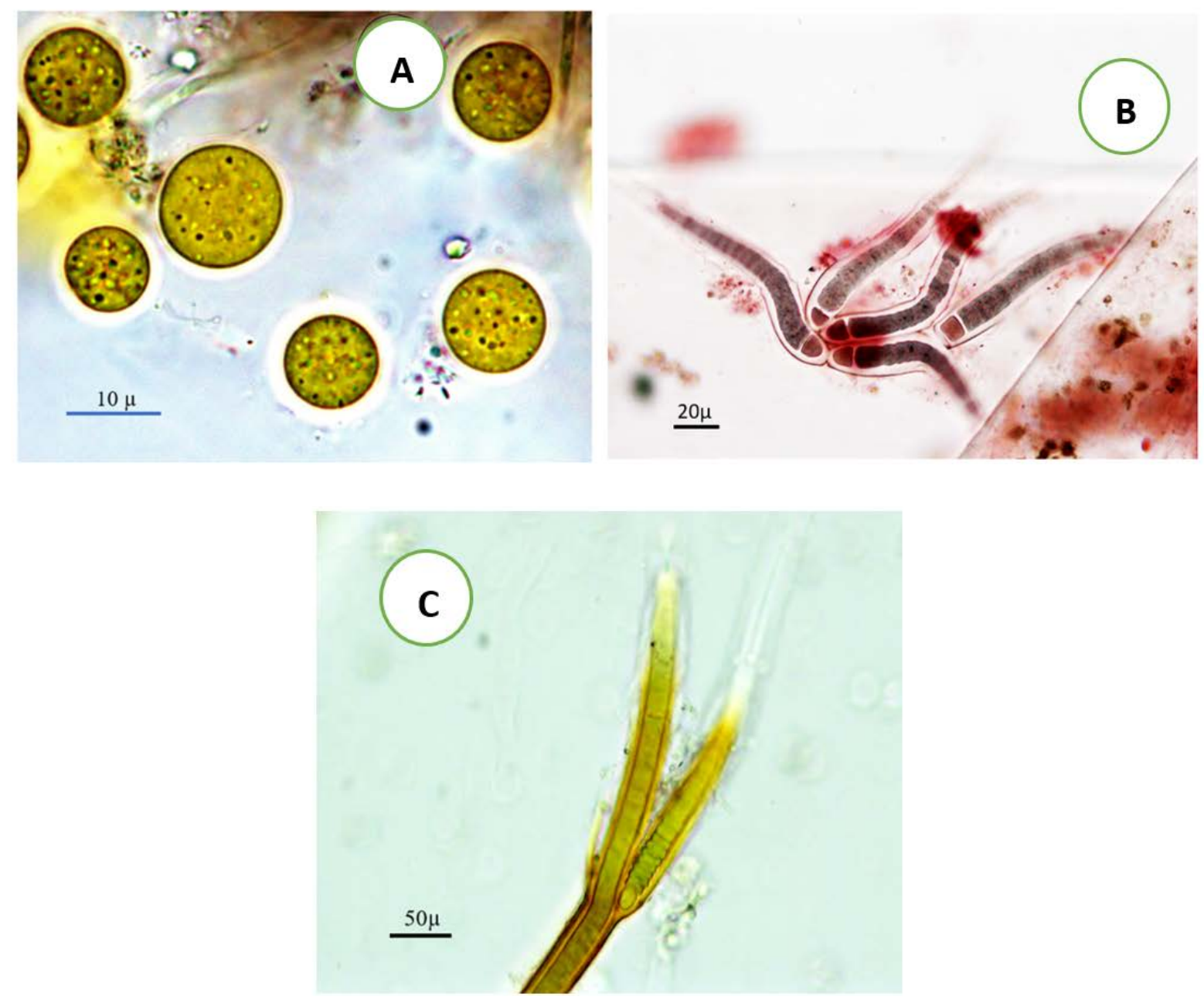

Fig. 5. Cyanothece halobia (A), unicellular greenish cells embedded by mucilage. Cells with many round granules. Rivularia bullata (B), epiphyte Trichomes with a basal heterocyst, a distinct taper to the trichome. Tolypothrix penicillate (C) filaments show false branches, delimited by a heterocyst. Sheaths are thin, colorless, and close to the trichome in young filaments.

\subsubsection{Unidentified marine algal species}

\subsubsection{Rhodophyta}

Gracilariales

Gracilariaceae

Gracilaria Greville, 1830.

Gracilaria sp. (figure 6A).

Thallus has a purplish-red color, terete, and subdichotomously - alternate and irregularbranches in one plane. The upper part of the thallus is more densely branched and forms a small bush. Branch margins are smooth, with no constricted base and tapering distally. Apices with a round shorted pointed tip; the final order of branches are bifurcate. The cross-section of the stipe shows that the medulla was composed of parenchymatous cells and surrounded by a few 
layers of small rounded cortical cells at the cortex. The sample did not match any Gracillaria species presently known from Kuwait. Records of Gracillaria for the region have been reviewed, such as G. pulvianata, G. arcuatae from Iran (Kokabi \& Yoysefzadi, 2015), and G. canaliculate from UAE (Al Abdessalaam, 2007), as well as Gracilariopsis longissima and G. persica from Iran (Bellorein et al., 2008, Sohrabipour \& Rabii, 1999). Additional studies are required to identify the species.

Location: Kuwait Towers, only one sample was collected from intertidal pools on rocks in March 2016.

\subsubsection{Bacillariophyta}

Bacillariophyceae

Naviculales

Berkeleyaceae

Parlibellus E.J. Cox, 1988.

Parlibellus sp. (figure 6B).

This genus is characterized by the presence of a straight raphe, which does not reach the end of the valve, by a thickened costa at the inner surface of the valve, and by the absence of septa. Valves are an elliptical oval-lanceolate shape, and the valve length varies. The valve ends are slightly beak-shaped and obtuse.

Two species of Parlibellus were recorded from the Arabian Gulf, P. crucicula by Al-Hindal (2009) and P. delognei (Vam Heurck) E.J. Cox by Basson \& Mohammed (1989). Parlibellus crucicula was later transferred to Prestauroneis crucicula by Genkal \& Yarushina (2017). More studies are needed to confirm the identity of the species.

Location: Kuwait Towers, tube-dwelling on the sand in the intertidal zone. November 2013. Naviculaceae

Schizonema, C. Agardh, 1824.

Schizonema sp. (figure 6C).

Resembling the description of Berkeleya rutilans (Trentepohl ex Roth) Grunow 1880.

Frond capillary throughout, frustules Navicula-shaped exceedingly crowded towards the apices. Filaments are long flaccid tenacious, like tufts of fine chestnut-colored hair. It is widely distributed in the sandy intertidal zone, at low tide, easily recognized by its color. Rerecorded from the coast of Saudi Arabia (Abdel-Kareem, 2009).

Location: Kuwait towers intertidal zone on sandy substrate. June 2014. 

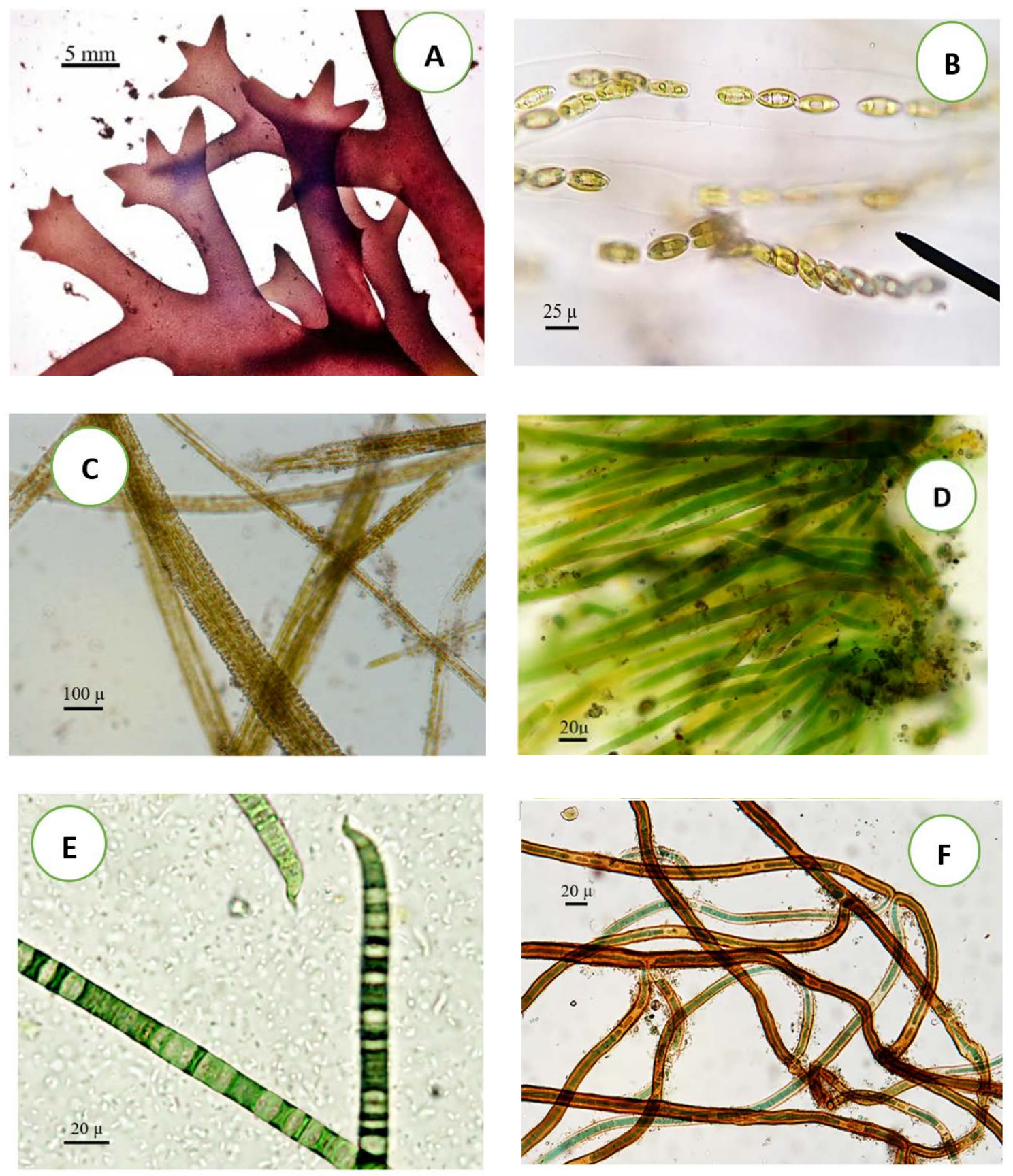

Fig. 6. Gracilaria sp. (A), thallus pinkish color, erect or decumbent, sub-dichotomously branched, branches terete to flattened with dentate tips. Parlibellus sp. (B), tube-dwelling diatoms. Valves are rhomboid or bluntly lanceolate. The central area is small and oval. Schizonema sp. (C), biofilm of diatoms on the sand. Filaments are long flaccid and firm, forming tufts brownish in color. Geitlerinema sp. (D-E), thallus thin, delicate, primarily bright blue-green forming thin mats; occasionally isolated trichomes. Sheaths absent. Filament with apical cells noticeably attenuated, hooked, and spherically capitated at the ends. Scytonema sp (F), trichomes uniseriate, isopolar, cylindrical, usually solitary heterocysts. Commonly falsely branched. 


\subsubsection{Cyanobacteria}

Oscillatoriales

Coleofasciculaceae

Geitlerinema (Anagnostidis \& Komarek) Anangnostidis, 1989.

Geitlerinema sp. (figures 6D-E).

Close similarity to Anagnostidinema lemmermannii (Woloszynska). Strunecky et.al., 2017. Filamentous thallus thin, delicate, primarily bright blue-green. The filament is composed of a single trichome. Trichomes are not constricted at the cross walls, lacking sheaths, and the morphology of the apical cells is bent, spherically capitate, and elongated when mature.

Location: Doha, in salt pools on the soil. October 2015.

Nostocales

Scytonematceae

Scytonema C.Agardh ex Bornet \& Flahault, 1886.

Scytonema sp. (figure 6F).

Hussain \& Khoja (1993).

Filaments form dark, brown-colored tufts. The trichomes are confined within a welldefined mucilaginous sheath. The trichomes are cylindrical, isopolar, and are usually colored pale blue-green to olive green. The apical ends of the filaments are not tapered, but the end cells may slightly be rounded. Heterocysts are located throughout the filaments and are rectangular and solitary. Double false branching is often formed. S. crispum (now Heteroscytonema crispum) from Iraq (Maulood et al., 2013) and S. hofmanni nom. invalid from Abu Dhabi (John \& George,1999) have been reviewed. More study is required to confirm the identity of the species.

Location: Failaka Island, on rocks and epiphyte on algae. March 2014.

\subsubsection{Marine phanerogams}

\section{TRACHEOPHYTA}

Liliopsida

Alismatales

Hydrocharitaceae

Halophila Du Petit-Thouars, 1806.

Halophila stipulacea *(Forsskål) Ascherson, 1867 (Published by Anonymous (1868). (figures 7A-B).

Lipkin 1975, Phillips \& Meñez 1988, Price \& Coles 1992, Kenworthy et al., 1993, Erftemeijer \& Shuail 2012.

Plant blades are elliptical, oblong, and pale to dark green with a length of 2-6 cm. Pairs of blades extend from each rhizome node on petioles and are covered at the base by folded and 
elliptic leaf scales 2-10 mm wide and 6-18 $\mathrm{mm}$ long. Blade margins, particularly at the apex, are serrated. Rhizomes are creeping, branched, and fleshy, and roots appear solitary at each node of the rhizome, unbranched and thick with dense, soft root hairs.

Location: Al-Nowaiseeb, only drifted samples in the intertidal zone. November, December 2014, 2015.
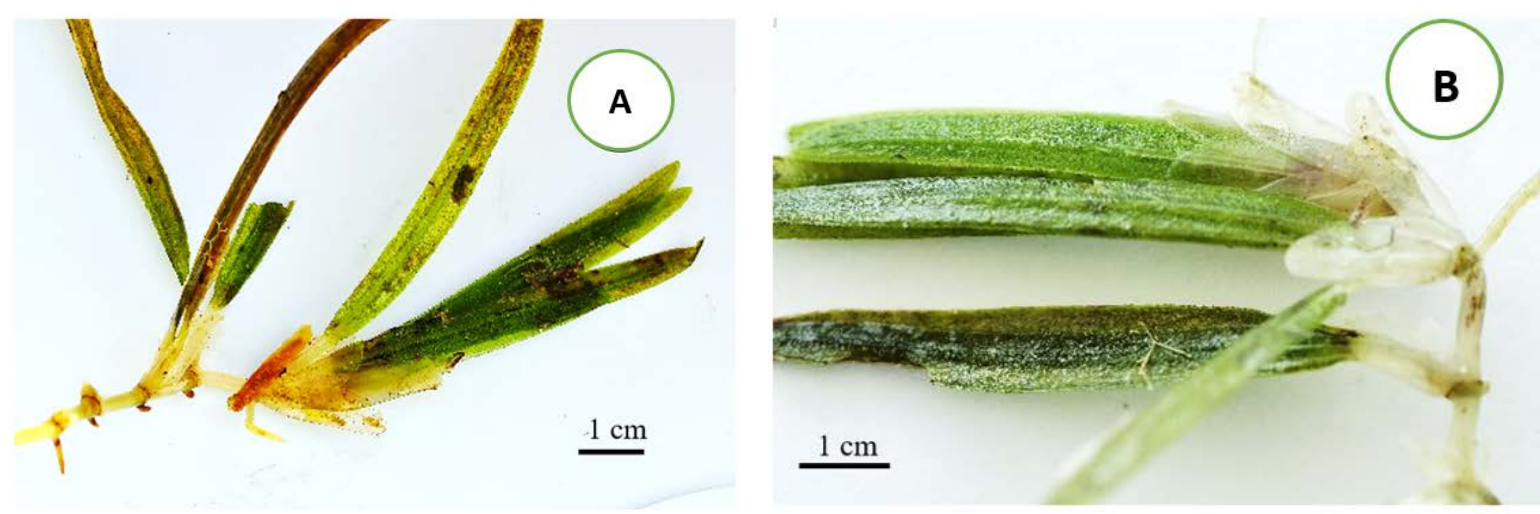

Fig. 7, Halophila stipulacea (A-B), rhizomes smooth with long internodes and leaf scars at the stem base. Roots are covered by tiny hairs and shoots, each carrying two linear leaf blades that contain mid and branched veins. The leaf margin is serrated, and minute trichomes may be present on one side of the leaf surface.

\section{Conclusion}

The study suggests that the rich benthic algal flora in the region of Al-Nuwaiseeb reflects a variety of biogeographical affinities and retains its natural flora. Hence, this region should be protected and preserved for its biodiversity. However, the algal status in Kuwait Bay suffers from anthropogenic effects, and the pollutants and high eutrophication levels adversely impact the loss of biodiversity. Therefore, particular attention should be made to studying the smaller and microscopic algal communities in this region.

Environmental measures must be made to remediate the Kuwait Bay marine environment. In addition, closer sampling methods and attention should be made to collecting and identifying smaller epiphytic and epilithic algae, which are usually overlooked in routine surveys.

\section{ACKNOWLEDGMENTS}

The authors thankfully acknowledge research grant \# KFAS P214-42SL-06 to carry out this work. We are greatly indebted to Professor Michael J. Wynne, Department of Biology, University of Michigan, for his very kind help and advice through the identification of the algal specimens. 


\section{References}

Abdel-Kareem, M.S.M. (2009). New algal records from the Arabian Gulf coast of Saudi Arabia. Botany Research International 2 (4)268-276.

Adanson, M. (1763). Familles des plantes. II. Partie [Vol. 2]. Pp. [1-24], [i-iii], [1]-640. Paris: Chez Vincent, Imprimeur-Librarie de Mgr le Comte de Provence, rue S. Servin.

Agardh, C.A. (1817). Synopsis algarum Scandinaviae, adjecta dispositione universali algarum. Pp. [i]-xl, [1]-135. Lundae [Lund].

Agardh, C.A. (1824). Systema algarum. Pp. [i]-xxxvii, [1]-312. Lundae [Lund]: Literis Berlingianis [Berling].

Agardh, J.G. (1851). Species genera et ordines algarum, seu descriptiones succinctae specierum, generum et ordinum, quibus algarum regnum constituitur. Volumen secundum: algas florideas complectens. Part 2, fasc. 1. Pp. 337 [bis]-351 [bis] 352-506. Lundae.

Al Abdessalaam, T.Z. (2007). Coastal and marine habitats. In: Al Abdessalaam, T.Z. (ed.): Marine Environment and Resources of Abu Dhabi, Pp. 55-91. Environment Agency, Abu-Dhabi and Motivate Publishing.

Allender, B.M. \& Kraft, G.T. (1983). The marine algae of Lord Howe Island (New South Wales): the Dictyotales and Cutleriales (Phaeophyta). Brunonia 6(1): 73-130.

Al-Hasan, R. H. \& Jones, W. E. (1989). Marine algal flora and seagrasses of the coast of Kuwait. J. Univ. Kuwait (Science)16: 289 - 340.

Al-Hindal, A.Y. (2009). Littoral diatoms from Shatt Al-Arab estuary north west Arabian Gulf. Cryptogamie Algologie 30(2): 153-183.

Al-Yamani, F.Y., Polikarpov, I., Al-Ghunaim, A. \& Mikhaylova, T. (2014). Field guide of marine macroalgae (Chlorophyta, Rhodophyta, Phaeophyceae) of Kuwait. First Edition, Kuwait Institute for Scientific Research (Publisher), 190 Pp. ISBN 978-99966-37-02-5.

Anagnostidis, K. (1989). Geitlerinema, a new genus of oscillatorialean cyanophytes. Plant Systematics and Evolution 164: 33-46

Ascherson, (1867). Published in: Anonymous (1868). Sitzungs-Bericht der Gesellschaft naturforschender Freunde zu Berlin am 15. Januar 1867: 1-4.

Basson, P. W. (1979a). Marine algae of the Arabian Gulf of Saudi Arabia (first half). Botanica Marina 22: 47-64. 
Basson, P. W. (1979b). Marine algae of the Arabian Gulf of Saudi Arabia (second half). Botanica Marina 22: 65-82.

Basson, P. W. (1992). Checklist of marine algae of the Arabian Gulf. Journal of the Univ. Kuwait (Science) 19: $217-232$.

Basson, P. W., Burchard, J. E., Hardy, J. T. \& Price, A. R. G. (1977). Biotopes of the western Arabian Gulf, Marine life and environments of Saudi Arabia. Pp 248. Aramco, Dhahran.

Basson, P.W \& Mohamed, S.A. (1989). The tube-dwelling diatom Nitschia martiana (C. A Agardh) Van Heurck as recorded from Bahrain (Arabian Gulf), Botanica Marina, 32: 253-257.

Basson, P. W., Mohamed, S. A. \& Arora, D. K. (1989). A survey of the benthic algae of Bahrain. Botanica Marina 32: 27 - 40.

Bellorin, A.M., A. Buriyo, J. Sohrabipour, M.C. Oliveira \& E.C. Oliveira (2008). Gracilariopsis mclachlanii sp. nov. and Gracilariopsis persica sp. nov. of the Gracilariaceae (Gracilariales, Rhodophyceae) from the Indian Ocean. Journal of Phycology 44(4): 10221032.

Berkeley, M.J. (1832). Gleanings of British algae; being an appendix to the supplement to English Botany, Pls 1-4. London: C.E. Sowerby.

Børgesen, F. (1905). Contributions à la connaissance du genre Siphonocladus Schmitz. Oversight Over Det Kgl Danske Videnskabernes Selskabs Forhandlingar 3: 259-291.

Børgesen, F. (1925). Marine algae from the Canary Islands especially Teneriffe and Gran Canaria. I. Chlorophyceae. Kongelige Danske Videnskabernes Selskab, Biologiske Meddelelser 5(3): 1-123.

Børgesen F. (1934). Some marine algae from the northern part of the Arabian Sea with remarks on their geographical distribution. Kongelige Danske Videnskabernes Selskab, Biologiske Meddelelser 11: 1-72.

Bornet, É. \& Flahault, C. (1886). Revision des Nostocacées hétérocystées contenues dans les principaux herbiers de France (Troisième fragment). Annales des Sciences Naturelles, Botanique, Septième série 5:51-129.

Cassano, V., Díaz-Larrea, J., Sentíes, A., Oliveira, M.C., Gil-Rodríguez, M.C. \& Fujii, M.T. (2009). Evidence for the conspecificity of Palisada papillosa with $P$. perforata (Ceramiales, Rhodophyta) from the western and eastern Atlantic Ocean on the basis of morphological and molecular analyses. Phycologia 48(2): 86-100. 
Cox, E.J. (1988). Taxonomic studies on the diatom genus Navicula. V. The establishment of Parlibellus gen. nov. for some members of Navicula sect. Microstigmaticae. Diatom Research 3(1): 9-38.

De Clerck, O. \& Coppejans, E. (1996). Marine algae of the Jubail Marine wildlife Sanctuary, Saudi Arabia. In: A Marine Wildlife Sanctuary for the Arabian Gulf Environmental Research and Conservation following the 1991 Gulf War Oil Spill. F. Krupp, A.H. Abuzinada \& I.A. Nader (Eds). NCWCD, Riyadh and Sensckenberg Research Institute, Frankfurt, Pp. 199-289.

Drew, K.M. (1956). Conferva ceramicola Lyngbye. Botanisk Tidsskrift 53: 67-74.

Erftemeijer, P.I.A \& Shuail, D, A, (2012). Seagrass habitats in the Arabian Gulf: distribution, tolerance thresholds and threats. J. Aquatic Ecosystem Health \& Management 15(1): 73-83.

Genkal, S.I. \& Yarushina, M.I. (2017). On the morphology and taxonomy of Parlibellus crucicula (Bacillariophyta). Inland Water Biology 10(4): 355-359.

Greville, R.K. (1823). Scottish cryptogamic flora, or coloured figures and descriptions of cryptogamic plants, belonging chiefly to the order Fungi; and intended to serve as a continuation of English Botany. Vol. 2 (fasc. 13-18), pls 61-90. Edinburgh \& London: MacLachlan \& Stewart; Baldwin, Craddock \& Joy.

Greville, R.K. (1830). Algae britannicae, or descriptions of the marine and other inarticulated plants of the British islands, belonging to the order Algae. Edinburgh \& London: McLachlan \& Stewart; Baldwin \& Cradock.

Grunow, A. (1880). Vorlaufige Bemerkungen zu einer systematischen Anordung der Schizonema- und Berkeleya-Arten, mit Bezug auf die in Van Heurck's Diatomeenflora von Belgien veröffentlichten Abbildungen der Frusteln auf Taf. XV, XVI und XVII. [Part] II. Botanisches Centralblatt 4(48): 1585-1598.

Guiry, M.D. \& Guiry, G.M. (2021). AlgaeBase. World-wide electronic publication, National University of Irland, Galway. https://www.algaebase.org; searched on 01 August 2021.

Harvey, W.H. (1855). Some account of the marine botany of the colony of western Australia. Transactions of the Royal Irish Academy 22: 525-566.

Hauck, F. (1887). Ueber einige von J.M. Hildebrandt im Rothen Meere und Indischen Ocean gesammelte Algen III, IV. Hedwigia 26: 18-21, 41-45.

Hommersand, M.H. (1986). The biogeography of the South African marine red algae: a model. Botanica Marina 29(3): 257-270. 
Howe, M.A. (1914). The marine algae of Peru. Memoirs of the Torrey Botanical Club 15: 1185 .

Hussain, M.I. \& Khoja, T.M. (1993). Intertidal and subtidal blue-green algal mats of open and mangrove areas in the Farasan Archipelago (Saudi Arabia), Red Sea. Botanica Marina 36: 377-388.

John, D.M. (2005). Marine plants. In: Hellyer P., Aspinall S. (eds). The Emirates. A natural history. Trident Press, London, Pp 161-167, 351-352.

John, D. \& George, D. (1999). Marine algal and invertebrate assemblages on hard substrata in Abu Dhabi, UAE. London: Natural History Museum.

John, D.M. \& Al-Thani, R.F. (2014). Benthic marine algae of the Arabian Gulf: a critical review and analysis of distribution and diversity patterns. Nova Hedwigia 98 (3-4): 341-392.

Jones, D.A. (1986). A field guide to the seashores of Kuwait and the Arabian Gulf. Pp.192. University of Kuwait, Blandford Press, UK.

Kenworthy, W.J., Durako, M.J., Fatemy, S.R., Valavi, H. \&Thayer, G.W. (1993).

Ecology of seagrasses in northeastern Saudi Arabia one year after the Gulf war oil spill. Marine Pollution Bulletin 27: 213-222.

Kokabi, M. \& Yousefzadi, M. (2015). Checklist of the marine macroalgae of Iran. Botanica Marina 58(4): 307-320.

Komárek, J. (1976). Taxonomic review of the genera Synechocystis Sauv. 1892, Synechococcus Näg. 1849, and Cyanothece gen. nov (Cyanophyceae). Archiv für Protistenkunde 118: 119-179.

Kützing, F.T. (1845). Phycologia germanica, d. i. Deutschlands Algen in bündigen Beschreibungen. Nebst einer Anleitung zum Untersuchen und Bestimmen dieser Gewächse für Anfänger, Pp. 1-340. Nordhausen: zu finden bei Wilh. Köhne.

Kützing, F.T. (1849). Species algarum. Pp. [i]-vi, [1]-922. Lipsiae [Leipzig]: F.A. Brockhaus. Lamouroux, J.V.F. (1813). Essai sur les genres de la famille des Thalassiophytes non articulées. Annales du Muséum d'Histoire Naturelle, Paris 20: 21-47, 115-139, 267-293.

Leliaert, F. \& Coppejans, E. (2006). A revision of Cladophoropsis Børgesen (Siphonocladales, Chlorophyta). Phycologia 45: 657-679.

Lipkin, Y. (1975). Halophila stipulacea, a review of a successful immigration. Aquatic Botany, 1: 203-215. 
Maulood, B.K., Hassan, F.M., Al-Lami, A.A., Toma, J.J. \& Ismail, A.M. (2013). Checklist of algal flora in Iraq. Pp. 1-94. Published in the Republic of Iraq by Ministry of Environment, Baghdad.

McCain, J.C. (1984). Marine ecology of Saudi Arabia. The nearshore, soft-bottom benthic communities of the northern sea, Arabian Gulf, Saudi Arabia. Fauna of Saudi Arabia 6: 79103.

McCain, J.C., Tarr, A.B., Carpenter, K.E. \& Coles, S.I. (1984). Marine ecology of Saudi Arabia. A survey of coral reefs and reef fishes in the northern area. Arabian Gulf, Saudi Arabia. Fauna of Saudi Arabia 6: 102-106.

Nam, K.W. (2007). Validation of the generic name Palisada (Rhodomelaceae, Rhodophyta). Algae (The Korean Journal of Phycology) 22(2): 53-55.

Newton, L. (1955). The marine algae of Kuwait. In Dickson, V. (ed): The wildflowers of Kuwait and Bahrain, Pp. 100-102. Allen \& Unwin, London.

Phillips, R. C. \& Menez, E. G. (1988). Seagrasses. Washington, D.C.: Smithsonian Institution Press: Contribution to Marine Science, No. 34, Pp104.

Price, A.R.G. \& Coles, S.L. (1992). Aspects of seagrass ecology along the western Arabian Gulf coast. Hydrobiologia 234: 129.

Rabenhorst, L. (1864). Flora europaea algarum aquae dulcis et submarinae. Sectio I. Algas diatomaceas complectens, cum figuris generum omnium xylographic impressis. Pp. 1-359.

Rabenhorst, L. (1865). Flora europaea algarum aquae dulcis et submarinae. Sectio II. Algas phycochromaceas complectens, Pp. 1-319.

Reinke, J. (1879). Zwei parasitische Algen. Botanische Zeitung 37: 473-478.

Reinsch, P.F. (1875). Contributiones ad algologiam et fungologiam. Vol. 1 pp. [i]-xii, [1]-103, I-XLII, XLIIa, XLIII-XLVII, XLVIIa, XLVIII-LXI (Rhodophyceae). Norimbergae [Nürnberg].

Richardson C.J. \& Hussain N.A. (2006). Restoring the Garden of Eden: an ecological assessment of the marshes of Iraq. BioScience 56(5): 477-489.

Roussomoustakaki, M. \& Anagnostidis, K. (1991). Cyanothece halobia, a new planktic chroococcalean cyanophyte from Hellenic heliothermal saltworks. Archiv für Hydrobiologie/Algological Studies 64: 71-95.

Setchell, W.A. \& Gardner, N.L. (1924). XXIX Expedition of the California Academy of Sciences to the Gulf of California in 1921. The marine algae. Proceedings of the California Academy of Science, Fourth Series, 12(29): 695-949. 
Sheppard, C., Price, A. \& Roberts, C. (1992). Marine ecology of the Arabian region, London: Academic Press, Vii: Pp 359.

Silva, P.C., Basson, P.W. \& Moe, R.L. (1996). Catalogue of the benthic marine algae of the Indian Ocean. University of California Press, Publ. in Botany, Vol. 79. ISBN 0-520-09810-2.

Sohrabipour, J. \& Rabii, R. (1999). A list of marine algae of seashores of the Persian Gulf and Oman sea in the Hormozgan province. Iranian Journal of Botany 8(1):131- 162.

Strunecky, O., Bohunická, M., Johansen, J.R., Capková, K., Raabová, L., Dvorák, P. \& Komárek, J. (2017). A revision of the genus Geitlerinema and a description of the genus Anagnostidinema gen. nov. (Oscillatoriophycidae, Cyanobacteria). Fottea, Olomouc, 17(1): 114-126.

Thouars, L.M.A. Du Petit (1806). Genera nova Madagascariensia secundum methodum Jussiaeanam disposita. Paris. DOI: 10.5281/zenodo.15463.

Wille, N. (1910). Conjugatae und Chlorophyceae [cont.]. In: Die natürlichen Pflanzenfamilien ... Nachträge zum I. Teil, Abteilung 2 über die Jahre 1890 bis 1910. (Engler, A. \& Prantl, K. Eds), Pp. 97-136. Leipzig: Wilhelm Engelmann.

Wynne M.J. (1991). A change in the name of the Type of Chondria C. Agardh (Rhodomelaceae, Rhodophyta). Taxon 40 (2): 316-318.

Wynne, M.J. (1999). New records of benthic marine algae from the Sultanate of Oman. Contributions from the University of Michigan Herbarium 22: 189-208.

Wynne, M. J. (2011). Proposal of the name Chaetomorpha vieillardii (Kütz.), n. comb., for a large-celled tropical Chaetomorpha (Chlorophyta). Pacific Science 65: 109-115.

Wynne, M.J. (2018). A checklist of the benthic marine algae of the northern Arabian Sea coast of the Sultanate of Oman. Botanica Marina 61(5): 481-498.

Submitted: $\quad 24 / 02 / 2021$

Revised: $\quad 26 / 08 / 2021$

Accepted: $\quad 30 / 08 / 2021$

DOI: $\quad 10.48129 /$ kjs. 12675 